\title{
STUDI PERBEDAAN ANTARA PRESTASI BELAJAR MANDIRI DENGAN BELAJAR PENDAMPINGAN MATA PELAJARAN PENDIDIKAN KEWARGANEGARAAN PADA SISWA TUNA WICARA SMALB
}

\author{
Retno Wati \\ Mahasiswa Pendidikan Pancasila dan Kewarganegaraan, Universitas Cokroaminoto Yogyakarta \\ Jl. Perintis Kemerdekaan, Gambiran, Pandeyan, Umbulharjo, Kota Yogyakarta 55161 \\ Email: watyberjuang@gmail.com
}

\begin{abstract}
ABSTRAK
Penelitian ini bertujuan untuk mengetahui perbedaan antara prestasi belajar mandiri dengan belajar Pendampingan dalam mata pelajaran PKn khususnya siswa tuna wicara kelas XI tingkat SMALB SLB Negeri 2 Bantul. Jumlah populasinya sebanyak 7 siswa dengan teknik sensus, populasi dijadikan penelitian. Dari hasil analisis diperoleh $\mathrm{t}$ hitung sebesar 13,28 sedangkan $\mathrm{t}$ tabel pada taraf signifikansi 5\% sebesar 2,26. Dengan $t$ hitung $>t$ tabel ada beda nyata prestasi belajar mandiri dengan belajar Pendampingan. Dengan demikian hipotesis "Diduga prestasi belajar siswa yang pendampingan lebih baik daripada prestasi belajar siswa yang belajar mandiri dalam mata pelajaran PKn pada siswa tuna wicara kelas XI tingkat SMALB SLB Negeri 2 Bantul Tahun Pelajaran 2016/2017" diterima.
\end{abstract}

Kata Kunci: Perbandingan, prestasi belajar mandiri, belajar pendampingan, PKn, SMALB

\section{ABSTRACT}

This study discusses the results of independent learning by assisting learning in PKB subjects specifically students of speech class XI SLALB SLB Negeri 2 Bantul. Total population of 7 students with census techniques, the population used as research. From the analysis results obtained t count of 13.28 while $t$ table at a significance level of 5\% of 2.26. With t arithmetic $>t$ table there is a difference in independent learning achievement with Mentoring learning. Thus the hypothesis "It is suspected that the learning achievement of students who are mentoring is better than the learning achievement of students who are self-learning in Civics subjects in speech impaired students of class XI SLALB SLB Negeri 2 Bantul 2016/2017 Academic Year".

Keyword: Comparison, independent learning achievement, mentoring learning, Civics, SMALB

\section{PENDAHULUAN}

Guru sangat berperan penting dalam kegiatan pembelajaran, karena guru bertanggungjawab terhadap tujuan pembelajaran yang ingin dicapai secara optimal. Selain sebagai tenaga pendidik dan pengajar tugas utama guru di sekolah adalah sebagai fasilitator sekaligus motivator. Pembelajaran yang menyenangkan diharapkan terjadi dalam pelaksanaan pembelajaran Pendidikan Kewarganegaraan (PKn), karena Pendidikan Kewarganegaraan (PKn) merupakan suatu konsep pembelajaran sosial dan mempunyai hubungan yang sangat luas terkait dengan kehidupan manusia. Temuan dilapangan yang berkenaan dengan proses pembelajaran PKn menunjukkan bahwa pendidik yang masih berkutat pada pola pengajaran konvensional dan belum mau belajar untuk menciptakan kondisi belajar yang menyenangkan dan bermakna. Proses 
pembelajaran dengan pola pengajaran konvensional lebih cenderung hanya mengantarkan siswa untuk mencapai tujuan mengejar target kurikulum seperti konsep-konsep penting, latihan soal dan tes tanpa melibatkan siswa secara aktif. Oleh karena itu, siswa kurang aktif dalam mengikuti pelajaran sehingga berdampak pada mandiri dalalm prestasi belajar siswa. Belajar mandirisiswa yang rendah akan diikuti oleh prestasi belajar siswa yang rendah. Paradigma siswa yang semula hanya menerima apa yang diberikan oleh guru dalam pembelajaran konvensional perlu diubah menjadi siswa sebagai penentu arah pembelajaran agar terjadi peningkatan mandiri dalam prestasi belajar PKn siswa. Peran siswa yang semula pasif menerima informasi dari gurunya harus diubah menjadi lebih aktif dalam belajarnya. Siswa harus dilibatkan dalam pengelolaan belajarnya di samping melatih mandirisiswa juga menjadikan siswa itu menjadi lebih bertanggungjawab terhadap belajarnya sendiri.

Permasalahan yang terdapat di sekolah luar biasa Negeri 2 Bantul meliputi (a) Perilaku Siswa. Banyak siswa yang memiliki perilaku menyimpang, terutama siswa yang sedang mengalami masa pubertas. Adapun perilaku menyimpang yang ada yaitu kelainan kleptomania di beberapa siswa SLB N 2 Bantul, kurangnya pemahaman seks di kalangan siswa sehingga menyebabkan masalah seperti terdapat video porno di handphone siswa, perilaku seks bebas di beberapa siswa serta tutur kata siswa yang kurang pantas. (b) keterampilan yang mencakup seluruh siswa, kebanyakan keterampilan yang diajarkan kepada siswa dilakukanberdasarkan tingkatan kelas tertentu. Hanya terdapat beberapa keterampilan yang dalam diakses oleh seluruh tingkatan kelas seperti melukis, sedangkan untuk keterampilan lainnya diajarkan pada tingkat kelas VI ke atas. Pada kelas pra-sekolah hingga kelas dasar belum diajarkannya keterampilan seperti kelas tingkat atas. (c) sumber belajar. Sumber belajar siswa di SLB N 2 Bantul diperoleh dari guru dan diaksesmelalui perpustakaan. Banyak siswa yang tidak memiliki buku peganganyang disebabkan siswa belum mampu memanfaatkan buku yang ada diperpustakaan dan jaringan internet yang ada di sekolah untuk mengakses informasi. Permasalahan lain yang timbul berkaitan dengan diterapkannya Kurikulum 2013 di beberapa kelas yang menyebabkan perlu adanya pembaharuan pada buku belajar yang ada di perpustakaan. Belum meratanya distribusi buku pelajaran dari pemertintah ke sekolah, sehingga guru maupun siswa kesulitan dalam mengakses buku. Bukuyang digunakan masih menggunakan buku KTSP sehingga perlu adanya penyesuaian dalam penggunaanya.

Guru yang efektif akan memulai pembelajaran dengan asumsi dasar bahwa semua siswa bersedia untuk belajar dengan sebaik-baiknya. Dengan demikian, penerapan studi belajar mandiri dengan belajar yang Pendampingan dapat meningkatkan pemahaman dan partisipasi siswa sehingga berujung pada peningkatan belajar mandiridalam prestasi belajar PKn. 
Berdasarkan uraian latar belakang tersebut penulis tertarik untuk melakukan penelitian tentang Studi Perbedaan antara Prestasi Belajar Mandiri dengan Belajar Pendampingan dalam Mata Pelajaran Pendidikan Kewarganegaraan (khususnya Siswa Tuna Wicara kelas XI) Tingkat SMALB SLB Negeri 2 Bantul Tahun Pelajaran 2016/ 2017.

Tujuan dari dilakukannya penelitian ini adalah ingin mengetahui perbedaan antara prestasi belajar mandiri dengan belajar Pendampingan siswa Tuna Wicara dalam mata pembelajaran PKn Tingkat SMALB SLB Negeri 2 Bantul. Mendapatkan informisasi tentang perbedaan antara prestasi belajar mandiri dengan belajar pendampingan siswa Tuna Wicara pada guru PKn SMALB SLB Negeri 2 Bantul.

Belajar mandiri adalah perilaku siswa dalam mewujudkan kehendak atau keinginannya secara nyata dengan tidak bergantung pada orang lain. Siswa mampu melakukan belajar sendiri, dapat mementukan cara belajar yang efektif, mampu melaksanakan tugas-tugas belajar dengan baik dan mampu untuk melakukan aktivitas belajar secara mandiri. Sebagaimana proses lainya, pola belajar ini mengikuti beberapa prosedur untuk bisa mencapai satu tujuan. Proses belajar mandri adalah suatu metode yang melibatkan siswa dalam tindakan-tidankan yang meliputi beberapa langkah, dan menghasilkan baik hasil yang tampak maupun yang tidak tampak.

Belajar pendampingan merupakan kegiatan untuk membantu individu maupun kelompok yang berangkat dari kebutuhan dan kemampuan kelompok yang Pendampingan dengan mengembangkan proses interaksi dan komunikasi dari, oleh, dan untuk anggota kelompok serta mengembangkan kesetiakawanan dan solidaritas kelompok dalam rangka tumbuhnya kesadaran sebagai manusia yang utuh, sehingga dapat berperan dalam kehidupan masyarakat sesuai dengan kemampuan yang dimiliki. Tuna wicara (bisu) adalah mereka yang menderita gangguan berbicara sehingga tidak dapat berbicara dengan jelas. Bisu disebabkan oleh gangguan pada organorganseperti tenggorokan, pitasuara, paru-paru,mulut, lidah, dan sebagainya.

\section{METODE PENELITIAN}

Tempat penelitian adalah lokasi dimana penelitian akan dilakukan sehingga diperoleh data yang digunakan untuk memecahkan permasalahan yang sedang diteliti. Dalam penelitian ini penulis mengambil tempat di SMALB SLB Negeri 2 Bantul. Sumber data dalam penelitian ini adalah data yang diperoleh langsung melalui wawancara dan observasi. Adapun sumber data dalam penelitian ini yaitu kepala sekolah SMALB N 2 Bantul, Guru PKn, dan siswa SMALB.

Sampel dalam penelitian ini didefinisikan sebagai individu yang merupakan bagian dari individu yang dapat mewakili seluruh populasi yang diteliti. Sedangkan menurut Sutrisno Hadi (1987:70) yang dimaksud "sampel adalah sebagian individu yang diselidiki". Dari pendapat 
diatas dapat disimpulkan bahwa sampel adalah sebagian individu yang merupakan wakil dari populasi yang diteliti. Adapun yang menjadi sampel siswayang dibedakan kelasXIA sejumlah 3 dan kelas XIB sejumlah 4 siswa. Teknik pengumpulan sampel menggunakan teknik sensu semua populasi dijadikan sampel. Pengambilan sampel didasarkan pada tujuan penelitian, yaitu untuk mengetahui perbedaan antara prestasi belajar mandiri dengan belajar pendampingan.

Analisa data adalah proses mengorganisasikan dan mengumpulkan datadalam pola, kategori dan satuan uraian dasar, sehingga dapat ditentukan temadan merumuskan hipotesis. Penggunaan uji $\mathrm{t}$ test independen, sering digunakan pengujian rancangan eksperimen, yang bertujuan untuk membandingkan nilai rata-rata dari perlakuan yang ada. Uji t termasuk dalam golongan statistika parametrik yang digunakan dalam pengujian hipotesis dan untuk mengetahui ada atau tidak perbedaan yang signifikan dari dua variabelyang dikomparasikan.

\section{HASIL PENELITIAN DAN PEMBAHASAN}

SMALB N 2 Bantul terletak di dusun Wojo, Bangunharjo Sewon, Bantul. Tepatnyadi Jalan Imogiri Barat Km. 4,5. Posisi sekolah dari jalan besar agak masuk sekitar $250 \mathrm{~m}$ dan dekat dengan lapangan olahraga. Walaupun letak sekolah tidak di pinggir jalan besar tetapi masyarakat luas sudah mengenalnya sejak berdirinya sekolah tersebut. Terbukti banyak masyarakat jauh dari lokasi sekolah yang mendaftarkan putra-putrinya masuk belajar diSLBN 2 Bantul.Lokasi Sekolah Luar Biasa Negeri 2 Bantul berada di lingkungan perkampungan tepatnya di Wojo Bantul.

Hasil wawancara peneliti dengan guru PKn kelas XI SLB N 2 bahwa penerapan belajar mandiri oleh guru PKn hanya meliputi melatih percaya diri,tanggung jawab saat pembelajaran sedang berlangsung. Peneliti juga melihat siswasangat bertanggung jawab dan peduli saat pembelajaran sedang berlangsung. Hal ini bisa dilihat saat guru sedang memberikan materi dan diberi kesempatan untuk dipelajari dan juga langsung dikerjakan tugas soal walaupun siswa tersebut berkebutuhan khusus. Hasil wawancara peneliti dengan guru PKn kelas XI SLB N 2 bahwa penerapan pendidikan belajar Pendampingan oleh guru PKn hanya meliputi nilai jujur, percaya diri, dan tanggung jawab disaat pembelajaran sedang berlangsung. Peneliti juga melihat siswa sangat bertanggung jawab dan peduli saat pembelajaran sedang berlangsung. Hal ini bisa dilihat saat guru sedang menerangkan materi didepan kelas langsung memperhatikan apa yang diberikan dan juga langsung dikerjakan tugas soal walaupun siswa tersebut berkebutuhan khusus.

Dari hasil observasi, peneliti melihat hanya beberapa siswa yang aktif.Untuk hasil belajar bisa di lihat ulang harian siswa yang memenuhi KKM. Dari hasil wawancara dan observasi di peroleh informasi adanya permasalahan dalam pembelajaran PKn yaitu siswa yang aktif dan 
kurang maksimalnya hasil belajar siswa. Dari permasalahan tersebut dapat diidentifikasikan faktor penyebab masalah yaitu pembelajaran dianggap kurang penting oleh siswa sehingga berakibat banyaknya nilai siswa yang tidak memenuhi KKM pada saat ulang harian, terdapat ketidaksesuaian antara beberapa guru PKn dalam mengajar sehingga membingungkan siswa, terdapat sebagian siswa yang kurang paham pada materi PKn dan istilah-istilah dalam pelajaran PKn masih dianggap rumit sehingga hasil belajarnya rendah, dan penerapan perbedaan antara prestasi belajar mandiri dengan Pendampingan yang diterapkan kepada siswa juga belum maksimal.

Guru masih banyak menerapkan model ceramah ketika mengajar, hal tersebut apabila dilakukan terus menerus akan menimbulkan kejenuhan pada siswa sehingga siswa kurang aktif dalam proses kegiatan belajar mengajar dan berakibat menurunnya hasil belajar mereka. Selain itu muatan nilai-nilai prestasi belajar mandiri juga belajar Pendampingan belum tampak baik dalam pembelajaran maupun siswa.

Mengatasi permasalahan tersebut diperlukan adanya suatu pembelajaran yang menarik, mudah dipahami, membuat aktif siswa, tidak membosankan yang dapat menumbuhkan interaksi dengan siswa lain guna mencapai tujuan pembelajaran dan penerapan perbedaan antara prestasi belajar mandiri dengan belajar Pendampingan yang di integrasikan dalam pembelajaran PKn. Salah satunya adalah melalui penerapan studi perbedaan antara prestasi belajar mandiri dengan belajar Pendampingan.

Sebelum melakukan tindakan, peneliti dengan guru pembimbing PKn melakukan perencanaan tindakan kelas yakni menyiapkan RPP sebagai bekal untuk mengajar, menyiapkan presensi siswa, membuat soaluntuk mengetahui hasil belajar siswa untuk melihat keaktifan siswa, menyiapkan materi yang akan disampaikan, dan membuat soal untuk siswa. Selanjutnya dalam pelaksanaan tindakan disajikan hasil penelitian dan pembahasan yang meliputi aktivitas dan hasil belajar PPKn siswa dengan studi perbedaan antara prestasi belajar mandiri dengan belajar Pendampingan. Indikator-indikator keaktifan yang diamati adalah sebagai berikut: (1) mendengarkan penjelasan guru, (2) menjawab pertanyaan guru, (3) siswa saat bertanya dan berpendapat, (4) tidak mengganggu teman.

a. Tidak melamun.

b. Berpegang teguh pada aturan yang ada dalam semua kegiatan.

c. Menyelesaikan tugas dengan baik.

d. Membantu teman jika mengalami kesulitan.

Indikator nilai-nilai belajar mandiri dengan belajar Pendampingan yang akan di terapkan adalah sebagai berikut: 
a. Jujur.

b. Disiplin.

c. Tanggung jawab.

d. Peduli.

Pelaksanaan penelitian ini berlangsung selama 2 pertemuan pada tiap-tiap pertemuan memiliki tahapan perencanaan, pelaksanaan, pengamatan, dan refleksi.

1. PertemuanPertama

a. Tahap Perencanaan

Peneliti dengan dibantu guru pembimbing melakukan persiapan dengan menyusun instrumen penelitian yang terdiri dari materi pembelajaran, lembar kerja serta hasil mengadakan kesepakatan dengan pengamat tentang tata cara mengisi lembar jawaban pada pelaksanaan pembelajaran. (RPP, materi pembelajaran, lembar kerja dan hasil belajar mandiri yang diperoleh).

b. Tahap Pelaksanaan

c. Implementasi tindakan pada pertemuanpertama dilakukan selama 1 kali pertemuan, perinciannya dapat disajikan sebagai berikut:

$\begin{array}{ll}\text { Hari/Tanggal } & \text { : Sabtu/ 29juli } 2016 \\ \text { Waktu } & \text { : Pukul 08.30- } 10.00 \text { WIB }\end{array}$

Tempat :SLB NEGERI 2 Bantul

Kelas : XIA

Jumlah $: 3$

Personel : Peneliti dan guru PPKn selaku pembimbing

Materi : Kedaulatan rakyat

Kegiatan yang dilakukan : Belajar mandiri

1) Kegiatan Awal

Pelaksanaan kegiatan pertemuan pertama dilakukan pada tanggal 29 juli 2016 pukul 08.30 WIB sampai pukul 10.00 WIB dan, dengan rincian sebagai berikut:

a) Mengucapkan salam.

b) Peneliti memperkenalkan diri.

c) Mengajak semua berdoa sesuai dengan agama dan kepercayaan masing-masing, untuk mengawali pelajaran.

d) Mempersiapkan kelas agar lebih kondusif untuk proses belajar mengajar, kerapian dan kebersihan ruang kelas, presensi, menyiapkan media, dan alat serta buku yang diperlukan.

e) Peneliti menyampaikan materi pembelajaran yang akan dilangsungkan. 
f) Sebelum peneliti menyampaikan tujuan pembelajaran, siswa diminta untuk membaca materi.

g) Peneliti menyampaikan tujuan pembelajaran.

Implementasi yang mencerminkan nilai religius pada kegiatan awal bisa dilihat dari mengucapkan salam.

2) Kegiatan Inti

Peneliti menyampaikan materi yang akan dibahas yaitu tentang kedaulatan rakyat dan sistem politik di Indonesia. Peneliti kemudian mengamati berbagai yang berkaitan dengan materi. Guru jelaskan yang diberikan materi untuk berbaca berkali-kali, setelah itu peneliti memberi selembar kertas isi soal materi untuk 3 siswamenjawab soal isi. Setelah selesai mengerjakan tugas, siswa diminta untuk dikumpulkan untuk dikoreksi. Setelah tadi, peneliti dan guru pembimbing memberikan nilai dari hasil belajar mandiri. Peneliti mengawasi dan mengamati jalannya belajar mandiri pada setiapsiswa.

Peneliti memintasiswa menyampaikan tanggapan atau pertanyaan dengan cara menulis mengenai jawaban siswa tuna wicara. Peneliti membuat peraturan yakni pertanyaan harus berbobot, tidak boleh melenceng dari topik, dan tidak boleh menjatuhkan siswayang sedang.

Setelah semua lembaran dikumpulan langsung dinilai, peneliti kembali mengulas kasus dan peneliti memberi kesempatan kepada siswa untuk berpendapat sesuai dengan apa yang mereka ketahui. Sebelum peneliti menyimpulkan materi, peneliti melakukan tanya jawab tentang materi yang telah dibahas. Implementasi belajar mandiri pada kegiatan ini bisa dilihat dari siswa percakapan dan penugasan, memperhatikan penjelasan guru mencerminkan sikap peduli. Saat mengerjakan tugas mencerminkan sikap percaya diri dan saat siswa menaati peraturan mencerminkan sikap tanggung jawab.

3) Kegiatan Penutup

Setelah siswa menyelesaikan tugas mereka yaitu berupa analisis kasus yang berkaitan dengan materi kedaulatan rakyat dan sistem politik di Indonesia dalam kontekssejarah kemudian peneliti menyimpulkan materi. Selanjutnya dilakukan :

a. Setelah memberikan lembaran materi setiap siswa disuruh membaca materi untuk mengerjakan tugas yang diberikan guru.

b. Sebagai tindak lanjut peneliti meneliti hasil pekerjaan siswa.

c. Mengakhiri pelajaran dengan mengajak semua siswa berdoa sesuai dengan agama dan kepercayaan masing-masing. 
Dari hasil belajar mandiri dapat diketahui nilai rata-rata kelas pertemuanpertama yaitu 26,7 .

4) Tahap refleksi

Pada tahap ini peneliti dan kolaborator mengadakan pertemuanpengamat menyampaikan hal-hal yang ditemukan selama tindakan. Peneliti mencatat sebagai masukan untuk bahan perbaikan pada tindakan berikutnya.

Dalam pelaksanaan kegiatan pembelajaran diperoleh informasi dari pengamatan sebagai berikut:

1. Memberikan materi untuk membaca berkali-kali

2. Saat mengerjakan tugas isi materi.

3. Persiapan pembentukan belajar mandiri harus diplaning sejak awal .

4. Soal analisis materi diberikan berupa materi.

2. Pertemuan Kedua

a. Tahap Perencanaan

Peneliti melakukan persiapan dengan menyusun instrumen penelitian yang terdiri dari materi pembelajaran, lembar kerja berupa analisis materi, serta mengadakan kesepakatan dengan pengamat tentang tata cara mengisi pada pelaksanaan pembelajaran. (RPP dan materi pembelajaran)

b. Tahap Pelaksanaan

Implementasi tindakan pada pertemuan kedua dilakukan selama 1 kali pertemuan, perinciannya dapat disajikan sebagai berikut:

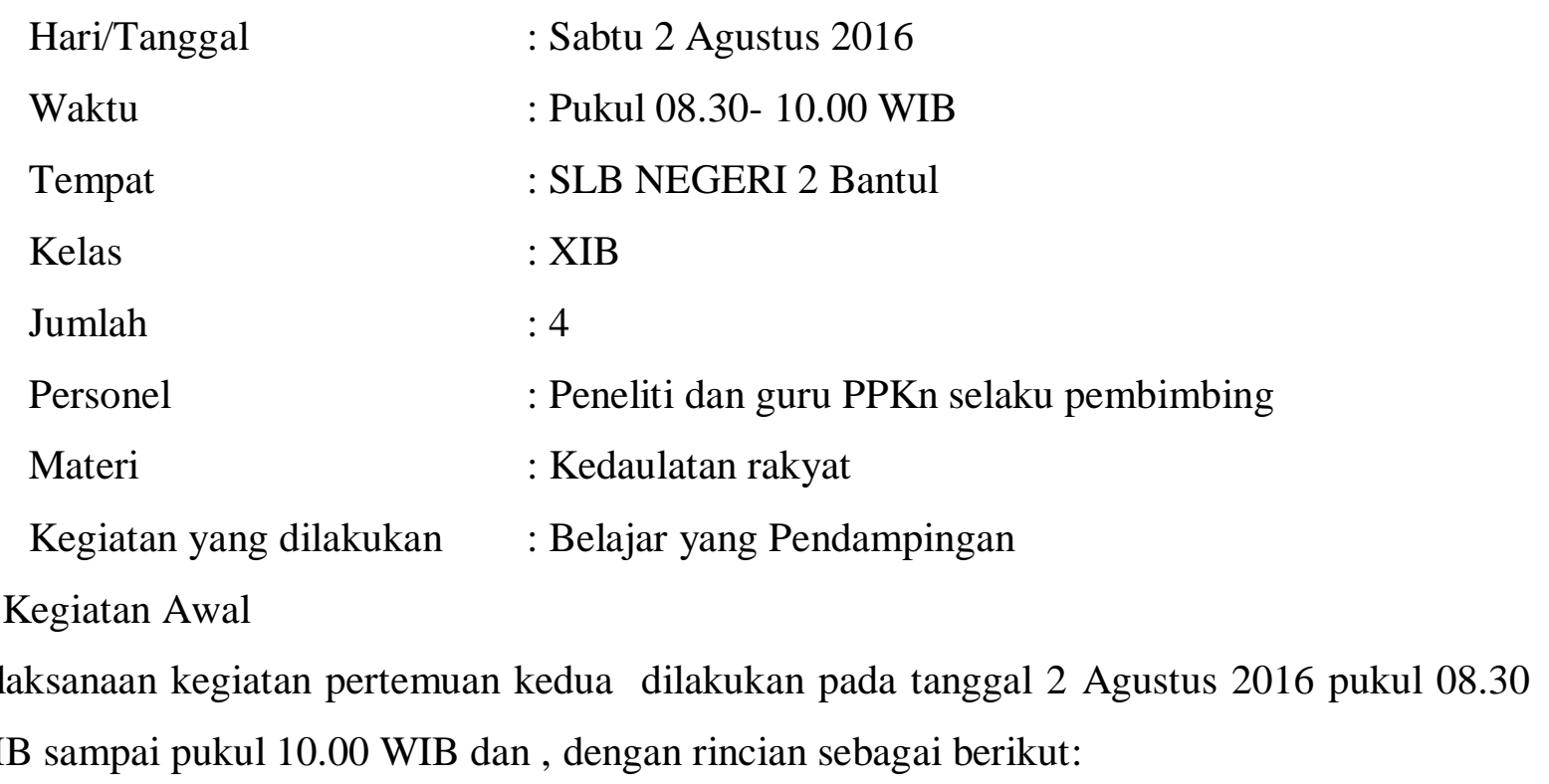

a) Mengucapkan salam. 
b) Mengajak semua berdoa sesuai dengan agama dan kepercayaan masing-masing, untuk mengawali pelajaran

c) Peneliti memperkenalkan diri.

d) Mempersiapkan kelas agar lebih kondusif untuk proses belajar mengajar, kerapian dan kebersihan ruang kelas, presensi, menyiapkan media, dan alat serta buku yang diperlukan.

e) Mengajak siswa bertanya jawab tentang kegiatan sebelum berangkat sekolah

f) Peneliti dan guru yang mendampingi dengan mempercakapkan arti kedaulatan berdasarkan yang diketahui dan menyampaikan materi pembelajaran yang akan dilangsungkan.

g) Sebelum peneliti menyampaikan tujuan pembelajaran, siswa diminta untukmemperhatikan materi yang disampaikan

h) Peneliti menyampaikan tujuan pembelajaran.

Implementasi yang mencerminkan nilai belajar Pendampingan pada kegiatan awal bisa dilihat dari mengucapkan salam.

2) Kegiatan Inti

Peneliti menyampaikan materi yang akan dibahas yaitu tentang kedaulatan rakyat dan sistem politik di Indonesia. Peneliti kemudian mengamati berbagai yang berkaitan dengan materi. Guru yang mendampingi menerangkan didepan kelas menyebutkan pengertian kedaulatan secara umum materi untuk berbaca berkali-kali,guru dan siswa mempercakapkan mengapa kedaulatan dibutuhkan dan bagaimana kedaulatan rakyat dijalankan memvisualisaikan di papan tulis dan juga melakuakn klarifikasi. setelah itu peneliti memberi selembar kertas isi soal materi untuk 4siswamenjawab soal isi. Setelah selesai mengerjakan tugas, siswa diminta untuk dikumpulkan untuk dikoreksi. Setelah tadi, peneliti dan guru pembimbing memberikan nilai dari hasil belajar mandiri. Peneliti mengawasi dan mengamati jalannya belajar Pendampingan pada setiap siswa.

Peneliti dan guru pembimbing meminta siswa menyampaikan tanggapan atau pertanyaan dengan cara menulis mengenai jawaban siswa tuna wicara. Peneliti membuat peraturan yakni pertanyaan harus berbobot, tidak boleh melenceng dari topik, dan tidak boleh menjatuhkan siswa yang sedang. Setelah semua lembaran dikumpulan langsung dinilai, peneliti kembali mengulas kasus dan peneliti memberi kesempatan kepada siswa untuk berpendapat sesuai dengan apa yang mereka ketahui. Sebelum peneliti menyimpulkan materi, peneliti melakukan tanya jawab tentang materi yang telah dibahas. Implementasi belajar mandiri pada kegiatan ini bisa dilihat dari siswa percakapan dan penugasan, memperhatikan penjelasan guru mencerminkan sikap kedaulatan. Saat mengerjakan tugas mencerminkan sikap percaya diri dan saat siswa menaati peraturan mencerminkan sikap tanggung jawab. 


\section{3) Kegiatan Penutup}

Setelah siswamenyelesaikan tugas mereka yaitu berupa analisis kasus yang berkaitan dengan materi kedaulatan rakyat dan sistem politik di Indonesia dalam kontekssejarah kemudian peneliti menyimpulkan materi. Selanjutnya dilakukan: (a) Siswa mencatat dibuku, (b) setelah memberikan lembaran materi setiap siswa disuruh membaca materi untuk mengerjakan tugas yang diberikan guru, (c) sebagai tindak lanjut peneliti meneliti hasil pekerjaan siswa, (d) mengakhiri pelajaran dengan mengajak semua siswa berdoa sesuai dengan agama dan kepercayaan masing-masing. Implementasi belajar Pendampingan pada penutup yaitu penerapan belajar mandiri ketika siswa mengerjakan tugas.

Selanjutnya, prestasi belajar yang pendampingan pada pertemuan kedua hasil belajar dapat diketahui nilai rata-rata kelas XIB pertemuan kedua yaitu 67,5.

\section{4) Tahap refleksi}

Pada tahap ini peneliti dan kolaborator mengadakan pertemuanpengamat menyampaikan halhal yang ditemukan selama tindakan. Peneliti mencatat sebagai masukan untuk bahan perbaikan pada tindakan berikutnya. Dalam pelaksanaan kegiatan pembelajaran diperoleh informasi dari pengamatan sebagai berikut:

1. Memberikan isi materi untuk membaca berkali-kali.

2. Saat mengerjakan tugas isi materi.

3. Persiapan pembentukan belajar mandiri harus diplaning sejak awal.

4. Soal analisis materi diberikan berupa materi.

Untuk melengkapi hasil penelitian maka menyajian data hasil penelitian test dapat disimpulkan bahwa yang mendapatkan nilai tertinggi adalah Retno Budi Anti dan nilai 80 adalah Farida Devi Anggraerni.

Analisis yang dilakukan pada penelitian ini perpedoman pada hipotesis penelitian yang ada, dengan uji-t sebagaimana telah dikemukan akan dimulai berhubungan sekolah menyelesaikan pokok bahasan belajar mandiri dengan belajar Pendampingan, maka penulis dan guru yang bersangkuatan hanya memberikan praktik dan mengajar. Penelitian mengambil sampel dua kelas yaitu XIA sampel yang menggunakan belajar mandiri sedangkan XIB sebagai sampel belajar Pendampingan tiap kelas berisi 3 siswa dan 4 siswa. Hasil analisis data penelitian dimaksud untuk mengetahui perbedaan antara prestasi belajar mandiri dengan belajar Pendampingan perhitungan $\mathrm{X}_{1}$ dan $\mathrm{X}_{2}$. Dari hasil penelitian ini memperoleh perhitungan yaitu dengan signifikan ( $\alpha$ ) 0,05 didapat $\mathrm{t}$ tabel $=2,145$ dengan hasil perhitungan $\mathrm{t}$ hitung $=13,28$ dengan demikian hipotesis nol di tolak analisis hipotesis kerja diterima. Hal ini menunjukan bahwa prestasi belajar 
siswa yang Pendampingan lebih baik dari pada prestasi belajar siswa yang belajar Pendampingan.

\section{KESIMPULAN}

Bertolak dari tindakan penelitian yang telah di lakukan, maka dapat disimpulkan Prestasi belajar siswa yang pendampingan lebih baik daripada prestasi belajar siswa yang belajar mandiri. Dari hasil analisis diperoleh t hitung sebesar 13,28 sedangkan t tabel pada taraf signifikansi 5\% sebesar 2,26. Dengan t hitung > t tabel ada beda nyata prestasi belajar mandiri dengan belajar Pendampingan. Dengan demikian hipotesis "Diduga prestasi belajar siswa yang pendampingan lebih baik daripada prestasi belajar siswa yang belajar mandiri dalam mata pelajaran PKn pada siswa tuna wicara kelas XI tingkat SMALB SLB Negeri 2 Bantul Tahun Pelajaran 2016/2017” diterima.

\section{SARAN}

Berdasarkan hasil penelitian, agar proses pembelajaran PPKn menarik, inovatif, mudah dipahami membuat siswa, serta menjadikan prestasi belajar siswa lebih baik dengan Pendampingan maka disimpulkan saran sebagai berikut:

1. Saran bagi Kepala Sekolah.

Hendaknya Kepada Sekolah sebagai pimpinan sekolah membuat kebijakan yang memacu siswa prestasi belajar yang Pendampingan lebih baik daripada belajar mandiri.

2. Saran bagi guru PPKn.

a. Bagi guru sebaiknya tetap menjaga hubungan baik dengan siswa SLB serta lebih bersabar dalam menghadapi siswa SLB.

b. Bagi guru sebaiknya sadar, bahwa belajar pendampingan sangat penting tetapi belajar mandiri juga sama pentingnya

3. Saran bagi siswa.

a. Perlu adanya kesadaran siswa bahwa pembelajaran PKn itu penting, sehingga dengan kesadaran siswa akan pentingnya pembelajaran PKn maka, dengan belajar keras mengingkatkan prestasi belajar.

b. Hendaknya siswa mampu belajar secara mandiri dan tidak tergantung kepada orang lain karena dengan mandiri siswa untuk belajar mandiri maka prestasi belajarnya akan meningkat. 
4. Saran bagi peneliti

Bagi peneliti selanjutnya diharapkan adanya penelitian lanjutan yang ada hubungan belajar mandiri dengan belajar Pendampingan, sehingga dapat menambah wawasan serta dapat pengetahuan tentang pentingnya kemandirian bagi kehidupan walaupun berkebutuhan khusus.

\section{DAFTAR PUSTKAKA}

Bowo, A. N. A. (2015). Pengembangan Pengelolaan Pembelajaran Ekonomi Berbasis Lingkungan dengan Strategi Small Group Discussion di SMA Muhammadiyah 1 Surakarta. Academy of Education Journal, 6(1).

Bowo, A. N. A. (2015). Cerita Cinta Belajar Mengajar. Deepublish.

Bowo, A. N. A. (2014). Small Group Discussion Berbasis Reading Guide untuk Peningkatan Keaktifan dan Hasil Belajar PKn Siswa MTs. Academy of Education Journal, 5(2).

Abdul Salim, 2000. Pemberdayaan Penyandang Cacat Menuju Kearah Kemandirian. Surakarta : PPRR Lemlit UNS

Abdurrachman, Muljono dan Sudjadi, (1994), pendidikan Luar Biasa Umum. Jakarta:Departemen pendidikan dan Kebudayaan.

Ancok, Djamaludin. 1991. Pengembangan dan Perluasan Kesempatan Kerja Dalam Rangka Peningkatan Kualitas Hidup Penyandang Cacat. Jakarta :Departemen Sosial RI Anonim. 1993.

Garis-garis Besar Haluan Negara.Jakarta : PT. Pabelan Boediono, 1996. Bimbingan dan Konseling. Direktorat Pendidikan Menengah. Jakarta.

Djummur dan Moh. Surya : 1993 : Bimbingan Konseling di Sekolah. Bandung :CV Ilmu. Haris Mudjiman. (2008). Belajar Mandiri. Surakarta: UNS Press.

Holstien. 1986. Murid Belajar Mandiri. Bandung: Cipta Karya

Ichrom, Moch. Sholeh.Y.A. 1996. Meningkatkan Motivasi dan Minat Siswa dalam Belajar. Jakarta : Dikdasmen Depdikbud. 